\title{
Dike-swarms, key to the reconstruction of major volcanic edifices: The basic dikes of La Gomera (Canary Islands)
}

\author{
E. Ancochea ${ }^{\mathrm{a}, *}$, J.L. Brändle ${ }^{\mathrm{a}}$, M.J. Huertas ${ }^{\mathrm{a}}, \mathrm{F}_{\text {. Hernán }}{ }^{\mathrm{b}}$, R. Herrera ${ }^{\mathrm{c}}$ \\ ${ }^{a}$ Dpto. Petrología y Geoquímica, Fac. Ciencias Geológicas, Inst. Geología Económica. (CSIC - Universidad Complutense), 28040 Madrid, Spain \\ ${ }^{\mathrm{b}}$ Dpto. Edafología y Geología, Universidad de La Laguna, 38206 La Laguna, Tenerife, Spain \\ c Área de Geología, ESCET, Universidad Rey Juan Carlos, 28933 Madrid, Spain
}

Received 27 July 2007; accepted 25 January 2008

Available online 20 February 2008

\begin{abstract}
The detailed study of the age and distribution of the basic dikes of La Gomera (Canary Islands) has allowed us to reconstruct the evolution of its main volcanic edifice. The dikes of the oldest unit (the Basal Complex) have a $\mathrm{N} 70^{\circ}-80^{\circ}$ dominant direction at regional scale. On the other hand, the dikes of the post Basal Complex subaerial units are the result of local stress fields. The oldest swarm is composed of sills dated at $10.2-$ 9.3 Ma. Four younger radial dike swarms have been identified (S1, S2, S3 and S4) with ages of 9.1-8.4 Ma; 8.2-6.7 Ma; 5.5-4.4 Ma and 5.34.0 Ma respectively. The reconstruction of the magmatic focus location using these swarms shows a migration southwards with an average speed of $1.6 \mathrm{~mm} /$ year. This temporal sequence of parallel swarms, sills and radial swarms is a pattern frequently repeated during the building of large insular volcanic edifices in the Canary Islands as well as in other archipelagos.
\end{abstract}

Keywords: basic dikes; radial dike swarms; sills; volcanic edifices; oceanic islands; Canary Islands; La Gomera

\section{Introduction}

In contrast to what is common to many other ocean islands (i.e. Hawaii) the growth of most of the Canary Islands was not rapid. On the contrary, these islands are the result of construction and destruction of successive large edifices covering a time span of several million years. Intrusion of magma has caused the development of an enormous amount of dikes that constituted step by step the main framework of the hypabyssal roots of these edifices.

Dike setting is controlled by regional and/or local stress fields existing at the moment when dikes intrude, so that they are a usual tool to infer the orientation of the main horizontal compressional stress. The complexity of the swarm structures reflects the complexity of the edifices history.

Dikes usually appear associated in swarms dominantly displaying parallel or radial distribution (Harker, 1904; Richey, 1939;

\footnotetext{
* Corresponding author.

E-mail addresses: geodec@geo.ucm.es (E. Ancochea),huertas@geo.ucm.es (M.J. Huertas), fherrnan@ull.es (F. Hernán), rherrera@geo.ucm.es (R. Herrera).
}

Anderson, 1951; Ode, 1957). Besides this, a swarm is defined as "an assemblage of dikes intruded during the same period of activity" (Speight et al., 1982). The extended activity on the Canary Islands has facilitated the succession of diverse swarms that have highly complicated the present general pattern of dikes in some of the islands, such as La Gomera. Nevertheless the interpretation of their complex geometry can be in turn a useful key to the understanding of the prolonged history of the island.

Intense erosion has exposed the deep roots of the oldest edifices on the Canary Islands, a fact that facilitates the possibility to carry out essential studies in the interpretation of their volcanic history. (i.e.: Schmincke, 1967; Hernán, 1976; Féraud et al., 1985; Stillman, 1987; Schirnick et al., 1999; Marinoni and Gudmunsson, 2000).

The analysis of dike swarms has already given excellent results in the reconstruction of old and deeply eroded edifices in some other islands such as La Palma (Staudigel et al., 1986; Ancochea et al., 1994), Tenerife (Ancochea et al., 1999), and Fuerteventura (Coello et al., 1992, Ancochea et al., 1993, 1996). The latter authors, for example, have shown that the island of Fuerteventura is the result of the alignment of three deeply 
eroded Miocene volcanic complexes paralleling the neighbouring West African coast. These three volcanic complexes, with independent volcanic histories, extended over more than 10 million years.

The island of La Gomera can be said to of special significance in the study of dike networks because the volcanic activity has lasted at least 8 million years, but its end, about some 2 million years ago, has permitted the exposure of multiple volcanic dike swarms.

The present paper introduces a detailed study carried out in the basic dikes network of La Gomera, using a methodology developed in previous studies by the authors (Brändle et al., 1991; Ancochea et al., 2003) that has provided an age for the different dike families, the location of the successive eruptive centres as well as the migration of the activity.

\section{Geological setting}

Among the papers studying the general evolution of $\mathrm{La}$ Gomera (a minor island of the Canarian archipelago, $380 \mathrm{~km}^{2}$ in surface area, circular in shape, and some $24 \mathrm{~km}$ in diameter with a maximum height of about $1500 \mathrm{~m}$ in the central area) a number can be highlighted: Bravo (1964), Hausen (1971), Cendrero (1970, 1971), Abdel Monen et al. (1971), Cubas (1978a,b), Cantagrel et al. (1984), Rodríguez Losada (1988), Paris et al. (2005) and Ancochea et al. (2003, 2006).

The oldest unit of La Gomera is the Basal Complex which crops out in a restricted area in the north (Fig. 1). The unit consists of mafic plutonic rocks, submarine alkali volcanic rocks and scarce marine sediments cut through by a highly dense network of dominantly basic dikes (Cendrero, 1970, 1971; Herrera et al., 2006). The whole represents the submarine growth stage (the Submarine Edifice) and the hypabyssal roots of the different growth stages recorded in the island (Ancochea et al., 2006). The age data obtained for this oldest unit range between 20 and $11 \mathrm{Ma}$ (Abdel Monen et al., 1971; Cantagrel et al., 1984; Herrera et al., 2006, personal communication).

The first subaerial edifice (the Old Edifice [OE] 10.56.4 Ma) (Cubas et al., 1994; Ancochea et al., 2006) was built up in two main stages. The first stage is represented by a large basaltic shield (the Lower Old Edifice [LOE]), of about $22 \mathrm{~km}$

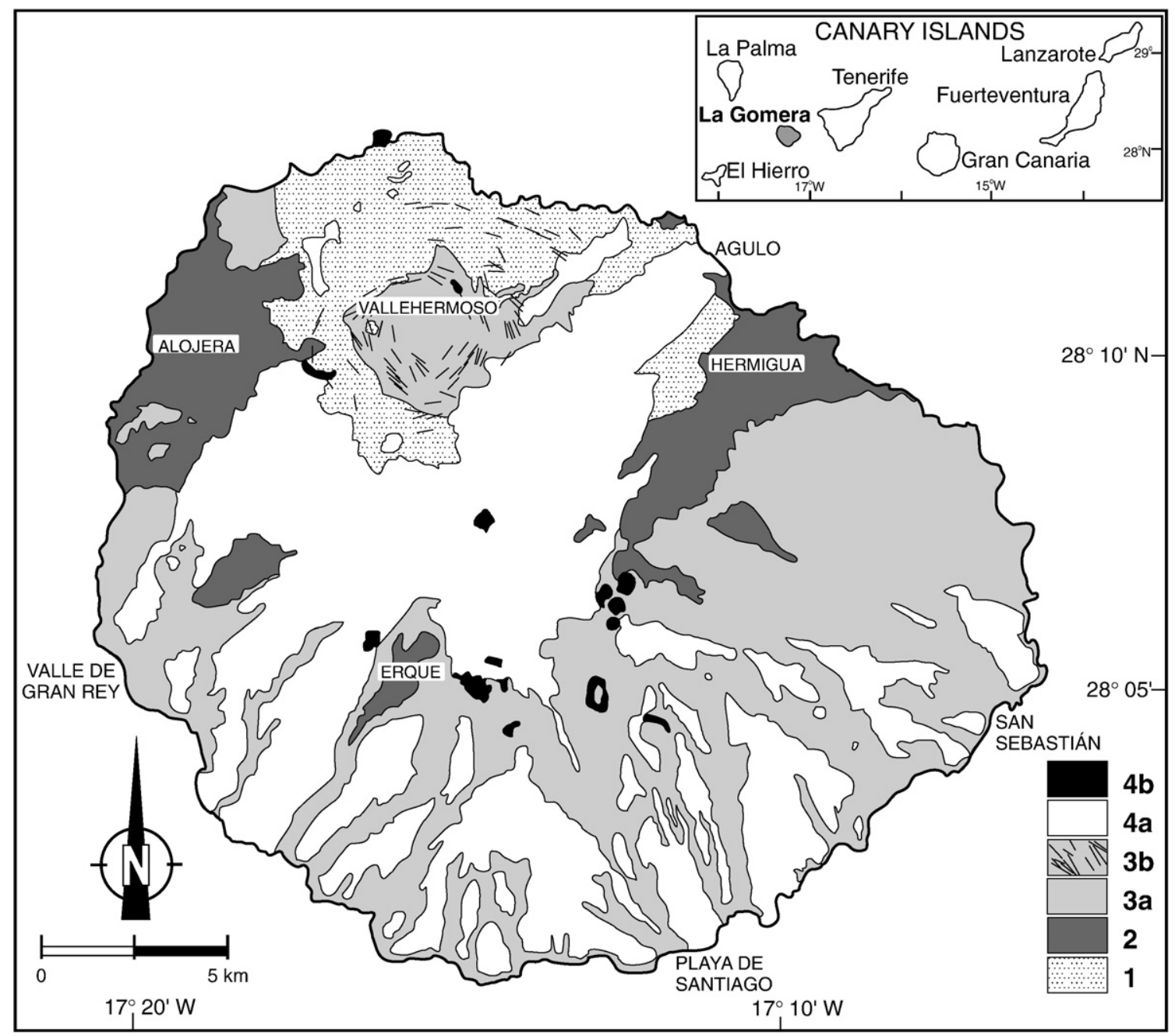

Fig. 1. Geological map of La Gomera (modified from Ancochea et al., 2006). 1: Basal Complex; 2: Lower Old Edifice (LOE); 3a: Upper Old Edifice (UOE); 3b: Vallehermoso felsic rocks; 4a: Young Edifice (YE); 4b: Young felsic domes. 


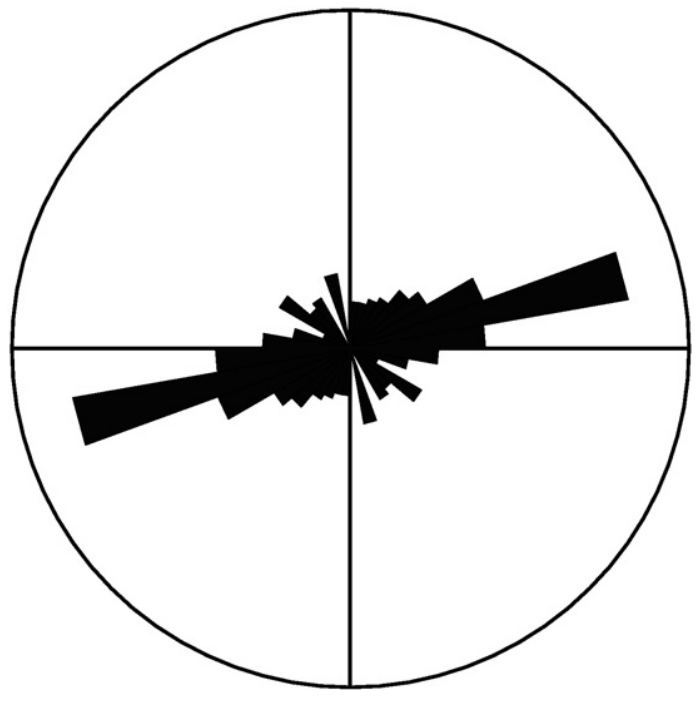

Fig. 2. Basal Complex dikes: dominant direction estimated from 250 sites of Cendrero (1971).

in diameter, whose centre would be located near Vallehermoso (Fig. 1), and would probably extend about $5 \mathrm{~km}$ offshore off the present northern coastline. The exposures of LOE (Alojera, Valle Gran Rey, Erque and Hermigua sectors, Fig. 1) alltogether shape a band surrounding almost entirely (except in the north) the Basal Complex and forms a pile several hundred meters thick of mostly ankaramitic or plagioclase-phyric pahoehoe lava flows. The lowermost flows exhibit submarine features (Cubas et al., 1994), while the subaerial upper ones alternate with thick volcanic breccias. Some important lateral collapses were responsible for the removal of a significant part of the northern shield flank (Ancochea et al., 2006).

Over the second growth stage an edifice $25 \mathrm{~km}$ in diameter (the Upper Old Edifice [UOE]) partly capped the earlier one. Two important trachytic to phonolitic episodes (one conical and two radial dike swarms) are associated with the activity of the UOE (Rodríguez Losada, 1987, 1988; Hernán et al., 2000; Huertas et al., 2000; Brändle et al., 2001; Ancochea et al., 2003; Rodríguez Losada and Martínez Frías, 2004).

The second large edifice (the Young Edifice [YE] 5.7-4 Ma) emitted lava flows that covered up the central and southern areas of the island whilst they only filled deep ravines already excavated on the northern flank (Fig. 1). In the early phase [YE-1] the lavas erupted from the central area of the island flowing essentially south and south-westwards. The late stage [YE-2] is mainly a sequence of horizontal lava flows covering the central area and different sectors in the north which is characterized by the absence of dikes. More differentiated magmas, including a significant amount of felsic magma (the third and last felsic episode), also were emitted in this phase of activity (Cubas et al., 2002).

\section{The basic dike swarms}

Dikes are one of the most characteristic and outstanding features of La Gomera. The very dense, mostly basaltic network of dikes in the Submarine Edifice (Basal Complex), studied by Cendrero (1971), is often affected by tectonics and shows quite different patterns to those exhibited by the dikes in the subaerial edifices. The amount of the Basal Complex dikes is estimated to be $60 \%$ of the total rock volume though the wall rock does not frequently exceed $10 \%$ of the whole exposure and even at some localities is practically absent. A subparallel pattern dominates sometimes whilst some others the crosscutting relationships are much more complex. All Basal Complex dikes are affected by different degrees of metamorphism. Cendrero (1971, figure 17) measured the main strikes at 250 sites. From the analysis of these measurements a dominant direction of $\mathrm{N} 70^{\circ}-80^{\circ}$ is estimated (Fig. 2).

The present work is essentially based on the analysis of the distribution of basic dikes intersecting the subaerial edifices that had not been studied in detail up to now. Bravo (1964) distinguished two main strikes of dikes: an older oriented NW-SE and a younger oriented E-W. On the other hand Féraud (1981) and Féraud et al. (1985) dated twelve dikes by K/Ar technique: four of the dikes with ages between 10.5 and 7.0 Ma, strike between $\mathrm{N} 90^{\circ} \mathrm{E}$ and $\mathrm{N} 140^{\circ} \mathrm{E}$, while eight younger ones, with ages comprised between 5.4 and $5.2 \mathrm{Ma}$, show multiple orientations following a general radial pattern.

The dikes intersect all of the subaerial units though are obviously more abundant in the lowermost units. Dikes are abundant and display complex patterns in the OE especially in the LOE where the normal density of dikes is one dike every 4$5 \mathrm{~m}$ of wall rock (Fig. 3). On the contrary, dikes in the YE are relatively scarce, especially in the upper unit (YE-2) where they are almost absent. Nevertheless, the dikes belonging to the YE edifice could be analysed where they intersect older units.

Two main types of dikes are easily distinguished in the subaerial units: vertical or subvertical dikes and slightly inclined dikes. Unlike the vertical ones, which exist in all the units, the inclined dikes are only visible in the LOE.

As most of the inclined dikes intrude more or less conformably to the LOE lava flows, they can be partly considered as sills. They are abundant (one every 5-6 m, Fig. 4) in the lowermost levels. Their number decreases upwards until completely disappearing near the top of the sequence. They are very

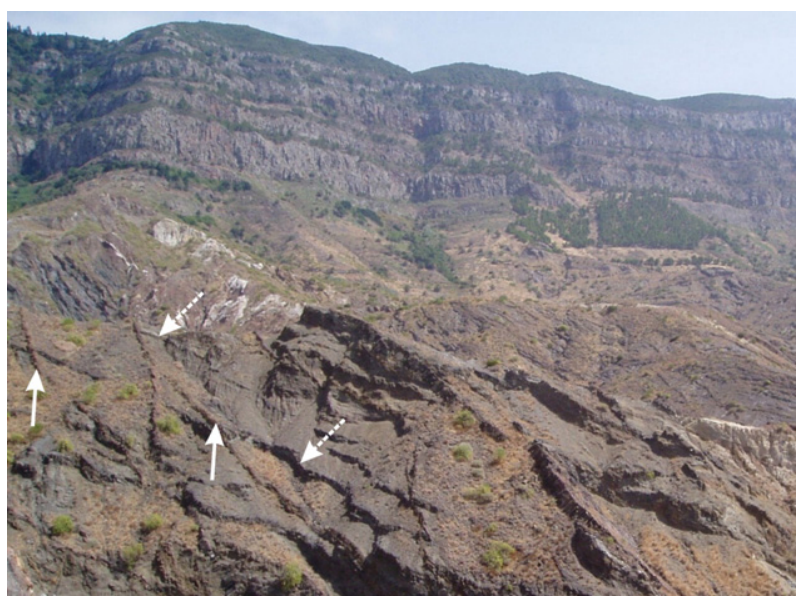

Fig. 3. LOE lava flows crossed by several dike sets in Alojera (in the foreground). Nearly horizontal YE lava flows on top (in the background). Dash arrows: sills; solid arrows: dikes of S1 and S2 swarms. 


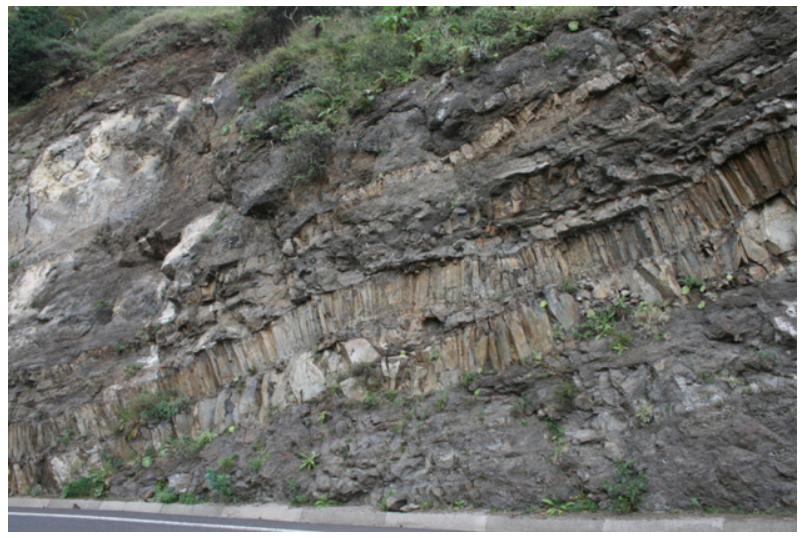

Fig. 4. Sills exhibiting columnar jointing intrude LOE pahoehoe lava flows in Hermigua.

rarely observed above 600 m.a.s.l. These dikes which are invariably basaltic show a dip lower than $30^{\circ}$ and locally, in part of their run, adapt themselves more closely to the dip of the lava flows which is only $7^{\circ}-10^{\circ}$. Similarly to the shield lava flows, the inclined dikes dip seawards, E and SE in Hermigua, W and SW in Alojera, and SSW in Valle Gran Rey (Fig. 1). Since the sills are systematically traversed by vertical or nearly vertical dikes they must necessarily be older.
The vertical dikes are much more abundant. A total of 1800 dip and strike measurements corresponding to 142 sites have been performed for those dikes. Fig. 5 shows the dyke trends; it is obvious that the number of dikes at each site is much lower in the southern sector of the island (where the YE materials appear) than in the north (where the OE materials crop out). At a first view, a simple radial distribution centred in the central core of La Gomera is deduced. Nevertheless, a more detailed observation reveals a quite more complex structure.

While at some sites the dike distribution is unimodal with a range of variation which does not exceed $15^{\circ}$, in others, the range is much greater and clearly bimodal or polimodal distribution patterns can be inferred, which indicates the existence of different swarms.

Fig. 6 shows the distribution of dike strikes in representative sites $(79,14,5,3,26$ and 54). Site 79 is located at relatively low stratigraphic levels of the OE. The numerous dikes here, exclusively basaltic in composition, display a principal disperse mode $\left(50^{\circ}\right)$ that might be due to the presence of more than one family of dikes whose directions partially overlap. Site 14 corresponds to somewhat higher stratigraphic levels in the $\mathrm{OE}$ sequence, where dikes are also relatively abundant (one every $10 \mathrm{~m}$ ); most of their strikes are comprised between $\mathrm{N} 80^{\circ}$ and $\mathrm{N} 110^{\circ}$. A dike with this strike, has given an age of $8.9 \mathrm{Ma} \pm$ $0.9 \mathrm{Ma}$ (G-145). Another dike from the same area belonging to a

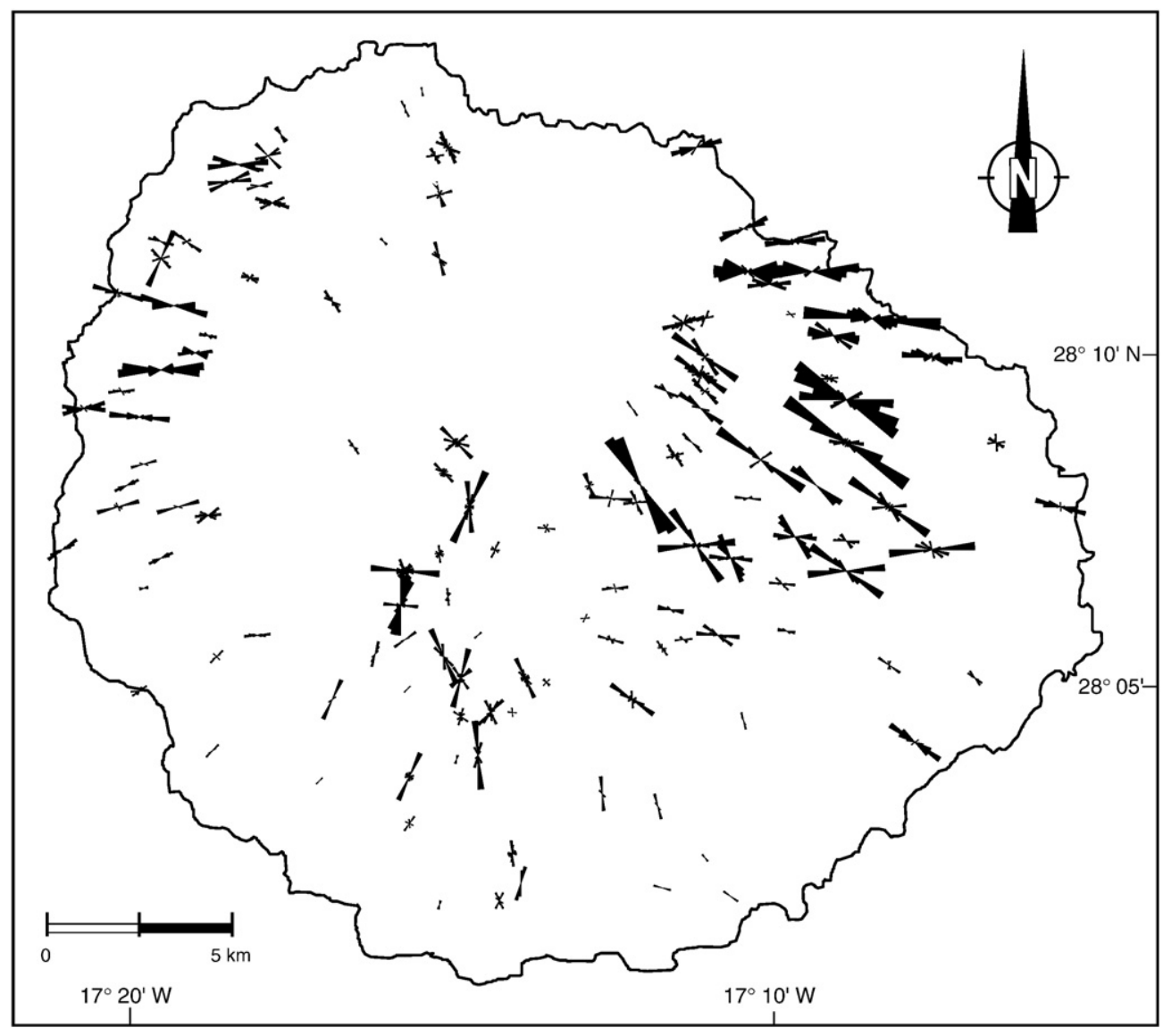

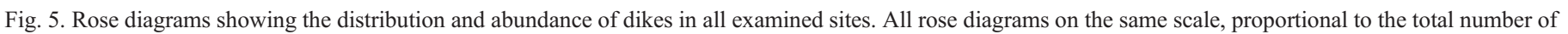
dikes measured on the island. 


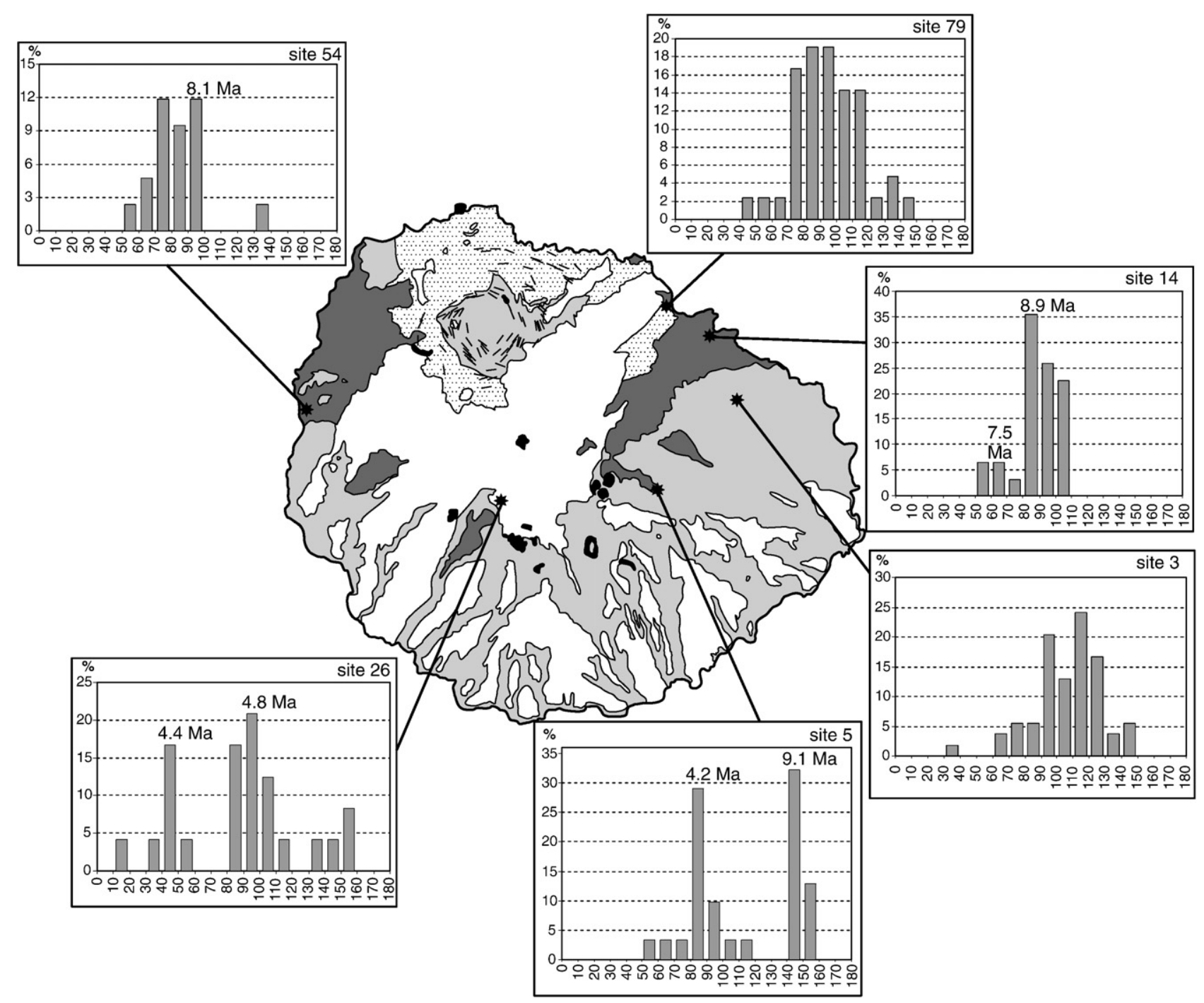

Fig. 6. Histogram showing the measured dike strikes in representative sites. The K/Ar ages available in each site are also shown.

less abundant and younger group, $\left(\mathrm{N} 50^{\circ}-\mathrm{N} 80^{\circ}\right)$ has a $\mathrm{K} / \mathrm{Ar}$ age of $7.5 \pm 0.4 \mathrm{Ma}$ (G-158, Table 1).

Site 5, also situated in LOE could well be considered as representative for all other sites in the eastern-central region of the island. A conspicuous bimodal distribution is observed here. Thin weathered basaltic dikes are cut across by thicker trachybasaltic and trachyandesitic dikes that typically stand out of the ground by differential weathering. A dike from the former group $\left(\mathrm{N} 140^{\circ}-150^{\circ}\right)$ has been dated to $9.1 \pm 0.5 \mathrm{Ma}$ (G-146) whereas a second dike from the latter $\left(\mathrm{N} 80^{\circ}-90^{\circ}\right)$ has given a much younger age of only $4.2 \pm 0.2 \mathrm{Ma}$ (G-148, Table 1 ). This distribution of dikes was considered by Bravo (1964) as representative for the island as a whole.

An intermediate situation is given in site 3, which is located in UOE. The two main maximum number of dikes observed $\left(\mathrm{N} 80^{\circ}-90^{\circ}\right.$ and $\left.\mathrm{N} 110^{\circ}-130^{\circ}\right)$ correspond to thin basaltic dikes. A third group $\left(\mathrm{N} 140^{\circ}-150^{\circ}\right)$ is defined by younger thicker and more differentiated dikes.

Site 26 is included in the YE. The dikes observed are basic or intermediate in composition and show a polimodal (variable) strike distribution including two maxima. A dike belonging to the first maximum $\left(\mathrm{N} 80^{\circ}-\mathrm{N} 110^{\circ}\right.$ strike range) has been dated to $4.8 \pm 0.2 \mathrm{Ma}(\mathrm{G}-187)$ and another dike from the second one $\left(\mathrm{N} 40^{\circ}-50^{\circ}\right)$ to $4.4 \pm 0.2 \mathrm{Ma}(\mathrm{G}-188$, Table 1$)$. A third maximum of much lesser importance $\left(\mathrm{N} 130^{\circ}-160^{\circ}\right)$ is also here appreciated (Fig. 6).

Finally, site 54 is representative for the western part of $\mathrm{OE}$ corresponding to upper levels of the LOE. The main mode is dispersed $\left(50^{\circ}: \mathrm{N} 50^{\circ}-99^{\circ}\right)$ or even slightly bimodal (Fig. 6). A $\mathrm{N} 90^{\circ}$ striking dike (Table 1) comprised in this mode has given an age of $8.1 \pm 0.5 \mathrm{Ma}(\mathrm{G}-178)$. A second mode $\left(\mathrm{N} 130^{\circ}-139^{\circ}\right)$ is less important.

The variability in the distribution of dike strikes in a single site depends on diverse factors such as: $a$ ) stratigraphic setting (the lower the level, the higher the number of dikes and families of dikes); b) proximity to the main eruptive centres (the closer the site, the higher the number of dikes and the variability of their strikes); c) position of the site relative to the eruptive centres (when a site is aligned with two or more different centres, the discrimination of dikes becomes uncertain). 
Table 1

Radiometric ages of rock-samples from basaltic dikes

\begin{tabular}{|c|c|c|c|c|c|c|}
\hline \multirow[t]{2}{*}{ Sample } & \multirow[t]{2}{*}{ Location } & \multicolumn{2}{|c|}{ UTM coordinates } & \multirow[t]{2}{*}{ strike } & \multirow[t]{2}{*}{$\%{ }^{40} \mathrm{Ar}^{*}$} & \multirow{2}{*}{$\begin{array}{l}\text { Age } \\
(\mathrm{Ma})\end{array}$} \\
\hline & & longitude W & latitude $\mathrm{N}$ & & & \\
\hline \multicolumn{7}{|c|}{ SILL SWARM } \\
\hline Go-57(*) & Alojera sea-cliff. & 270980 & 3117530 & - & 18.1 & $10.2 \pm 0.5$ \\
\hline G-22 & Hermigua. Basaltic sill & 287100 & 3116850 & - & 49.0 & $9.4 \pm 0.6$ \\
\hline G-7 & Alojera. Pyroxenic basaltic sill & 272400 & 3117600 & - & 39.9 & $9.3 \pm 0.8$ \\
\hline \multicolumn{7}{|c|}{ S1 SWARM } \\
\hline G-146 & Barranco de Las Lajas. & 284330 & 3111750 & $\mathrm{~N} 145^{\circ}$ & 68.1 & $9.1 \pm 0.5$ \\
\hline G-160 & $\begin{array}{l}\text { Barranco de Valle Gran Rey. } \\
\text { Hermitage de los Reyes. }\end{array}$ & 272190 & 3111300 & $\mathrm{~N} 59^{\circ}$ & 59.4 & $8.9 \pm 0.4$ \\
\hline G-145 & Hermigua. Road to the old dock & 286800 & 3118750 & $\mathrm{~N} 86^{\circ}$ & 25.5 & $8.9 \pm 0.9$ \\
\hline G-185 & Barranco de Erque. & 277400 & 3110100 & $\mathrm{~N} 7^{\circ}$ & 48.5 & $\mathbf{8 . 8} \pm \mathbf{0 . 4}$ \\
\hline G-182 & Alojera. & 272400 & 3117500 & $\mathrm{~N} 86^{\circ}$ & 60.3 & $8.4 \pm 0.4$ \\
\hline \multicolumn{7}{|c|}{$S 2 S W A R M$} \\
\hline G-186 & Barranco de Erque. & 277700 & 3110300 & $\mathrm{~N} 45^{\circ}$ & 62.3 & $8.2 \pm 0.4$ \\
\hline G-178 & Taguluche. & 270500 & 3114900 & $\mathrm{~N} 90^{\circ}$ & 37.2 & $8.1 \pm 0.5$ \\
\hline G-158 & Hermigua. & 286625 & 3118250 & $\mathrm{~N} 66^{\circ}$ & 44.9 & $7.5 \pm 0.4$ \\
\hline G-152 & Barranco de Las Lajas. & 287140 & 3111850 & $\mathrm{~N} 133^{\circ}$ & 42.5 & $7.4 \pm 0.4$ \\
\hline G-171 & Punta Llana. & 293260 & 3112550 & $\mathrm{~N} 105^{\circ}$ & 57.4 & $6.9 \pm 0.3$ \\
\hline G-156 & El Rejo. & 283800 & 3113550 & $\mathrm{~N} 105^{\circ}$ & 55.4 & $6.7 \pm 0.3$ \\
\hline \multicolumn{7}{|c|}{ S3 SWARM } \\
\hline G-163 & Cherelepín. & 279250 & 3112550 & $\mathrm{~N} 170^{\circ}$ & 49.4 & $5.5 \pm 0.3$ \\
\hline G-155 & El Rejo. & 284240 & 3113750 & $\mathrm{~N} 47^{\circ}$ & 48.1 & $5.3 \pm 0.3$ \\
\hline G-175 & Jerduñe. & 285100 & 3109500 & $\mathrm{~N} 95^{\circ}$ & 61.9 & $5.1 \pm 0.3$ \\
\hline G-199 & Halfway to Benchijigua. & 283250 & 3108500 & $\mathrm{~N} 121^{\circ}$ & 62.4 & $4.9 \pm 0.2$ \\
\hline G-159 & Road Arure - Valle Gran Rey. & 272450 & 3112510 & $\mathrm{~N} 105^{\circ}$ & 50.6 & $4.8 \pm 0.2$ \\
\hline G-192 & Imada. & 279500 & 3108200 & $\mathrm{~N} 18^{\circ}$ & 42.9 & $4.7 \pm 0.2$ \\
\hline G-188 & Barranco de Erque. & 277750 & 3111100 & $\mathrm{~N} 50^{\circ}$ & 50.5 & $4.4 \pm 0.2$ \\
\hline \multicolumn{7}{|c|}{ S4 SWARM } \\
\hline G-174 & Jerduñe. & 285050 & 3109400 & $\mathrm{~N} 124^{\circ}$ & 70.3 & $5.3 \pm 0.3$ \\
\hline G-187 & Barranco de Erque. & 277700 & 3110985 & $\mathrm{~N} 92^{\circ}$ & 55.3 & $4.8 \pm 0.2$ \\
\hline G-191 & Imada. & 279500 & 3107900 & $\mathrm{~N} 45^{\circ}$ & 37.2 & $4.2 \pm 0.3$ \\
\hline G-148 & Barranco de Las Lajas. & 284950 & 3111300 & $\mathrm{~N} 82^{\circ}$ & 49.3 & $4.2 \pm 0.2$ \\
\hline G-198 & Road Arure - Valle Gran Rey. & 272600 & 3112700 & $\mathrm{~N} 76^{\circ}$ & 45.0 & $4.0 \pm 0.2$ \\
\hline
\end{tabular}

Data of Ancochea et al. (2006), ${ }^{(*)}$ Cantagrel et al. (1984).

From the analysis of the above and other sites, a coexistence of multiple patterns of dikes is easily deduced: at least two families related to the $\mathrm{OE}$ (sites 3, 14 or 79) and two families to the YE (site 26).

\section{Locating the magmatic focus}

On the basis of the above premises, the interpretation started with the sites where dikes showed less complex relationships corresponding to the youngest levels. The temporal control was established either by the observed crosscutting relationships or by the existence of radiometric age data obtained from wall rocks, dikes or both. In the case of sites located at lower stratigraphic levels we only used, in this preliminary phase, the strikes of dated dikes as well as those corresponding to other dikes that could be correlated by the intrusion relationships.

These dike strikes were used to deduce the position of the centre (magmatic focus) from which dikes extend. The method of the "maximum intersections" developed by the authors (Brändle et al., 1991), similar in some respect to that of Frost
(1965), is a mathematical method for the identification of radial dike swarms and the location of their convergence centres, that has been applied successfully in the reconstruction of deeply eroded basaltic shields on Fuerteventura (Ancochea et al., 1993, 1996). This method has also been used in La Gomera in order to deduce the geometry of the felsic dyke swarm of the northern area (Ancochea et al., 2003). Each dike is considered as a straight line. In theory all lines (dikes) would converge at a single centre, nevertheless, in reality every pair of dikes converge on a point close to the centre of the structure. According to our method, the area where the intersections of lines reach a maximum, represent the hypothetical centre of the swarm.

Not all intersections are admitted as valid. For example, intersections of very closely spaced dikes are ignored, as well as those showing a very small angle (less than $10^{\circ}$ ) or those occurring too far away (at more than $15 \mathrm{~km}$, maximum radius of the island).

Once the location of the centre is deduced, the magmatic focus can be considered as a circular area. For any dike to be interpreted as belonging to a particular magmatic focus, it has to 
be verified that the extension of its trend intersects the corresponding circular area.

The remaining dikes (those not justified by the estimated centre) are interpreted as belonging to a different system. This process is repeated several times successively analysing dikes intruding lower stratigraphic levels.

New radiometric ages were determined, when needed, in order to corroborate the results previously obtained. Table 1 shows data corresponding to the dated dikes; more detailed analytical data concerning these radiometric ages $(28$ as a whole) are found in Ancochea et al. (2006) where the authors made use of these data to elaborate a general volcano-stratigraphic model for La Gomera.

Once all the possible centres are identified, and keeping stratigraphic coherence (the existence of old dikes in sites located in younger wall rock is not feasible) all sites are again analysed underlining which dikes are oriented towards each centre.

\section{The four radial swarms}

By applying the method explained in the previous section, four main radial dike swarms are distinguished and designated in chronological order as: S1, S2, S3 and S4. Fig. 7 shows separately the centres to which each one of these four dike families converge $(\mathrm{C} 1, \mathrm{C} 2, \mathrm{C} 3$ and $\mathrm{C} 4)$ defined as the four corresponding areas where the number of intersections is maximum. The dikes belonging to their correspondent swarms and their respective ages are also seen in this figure.

$84 \%$ of the strikes measurements is coherent with one or more of the four swarms. $29 \%$ of the total amount of measured dikes belongs to S1 and include 122297 valid intersections that are consistent with the criteria mentioned above. The centre of the oldest swarm is located in an area around a point having UTM coordinates of $280.250,3.118 .450$ (C1, Fig. 7); $88 \%$ of the valid intersections is situated within a radius of $2.5 \mathrm{~km}$ around $\mathrm{C} 1$.

This swarm (S1) includes dikes dated between 9.1 and 8.4 Ma (Table 1) characterized by their frequently ankaramitic basaltic composition and an average thickness of about $1 \mathrm{~m}$ ( $87 \%$ of them is less than $1.5 \mathrm{~m}$ thick). The median is estimated at $0.80 \mathrm{~m}$ (Fig. 8).

Swarm S2 is defined by $20 \%$ of the total amount of dikes measured in the field giving rise to 56379 valid intersections. The corresponding centre $(\mathrm{C} 2$, Fig. 7) is located at a point given by 280.610 and 3.115.010 (UTM coordinates). A circle $2.5 \mathrm{~km}$ in radius around that point includes $89 \%$ of the total intersections. These dikes have younger ages ranging between 8.2 and $6.7 \mathrm{Ma}$ (Table 1). Their composition and thickness are similar to those of the older S1 dikes (average of $0.8 \mathrm{~m}, 94 \%$ of them is less than $1.5 \mathrm{~m}$ thick as for $\mathrm{S} 1$ and a slightly lower median of $0.60 \mathrm{~m}$ ).
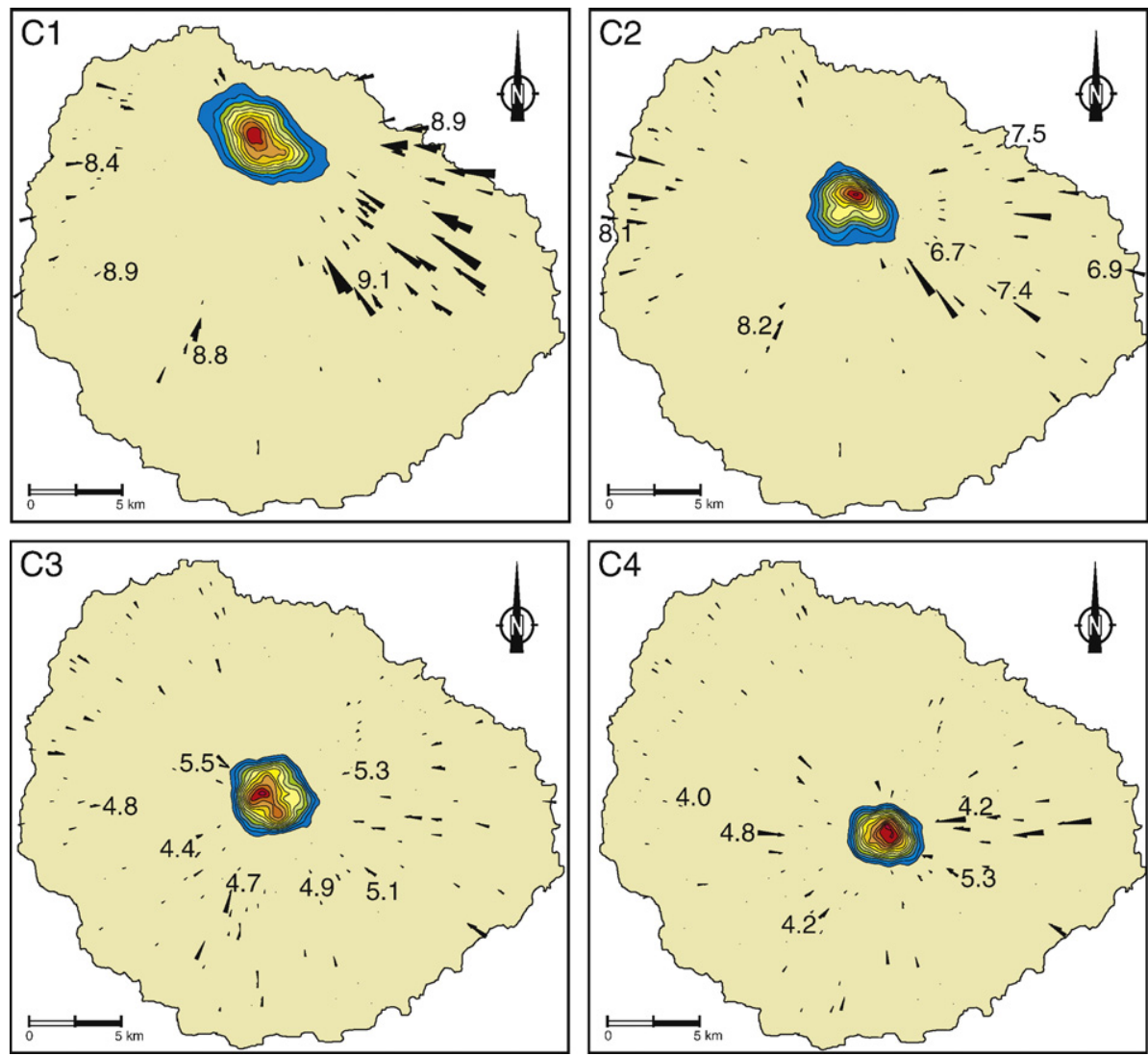

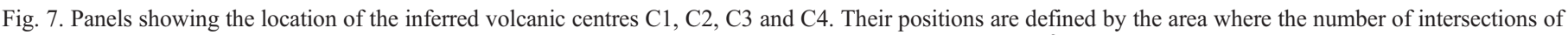

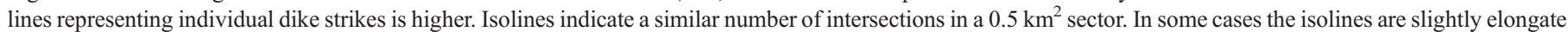

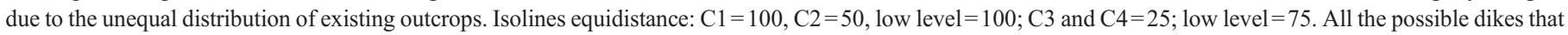
could be ascribed to each one of the swarms are visualized in the four panels. Figures next to dike symbols represent K/Ar radiometric ages (Table 1). 

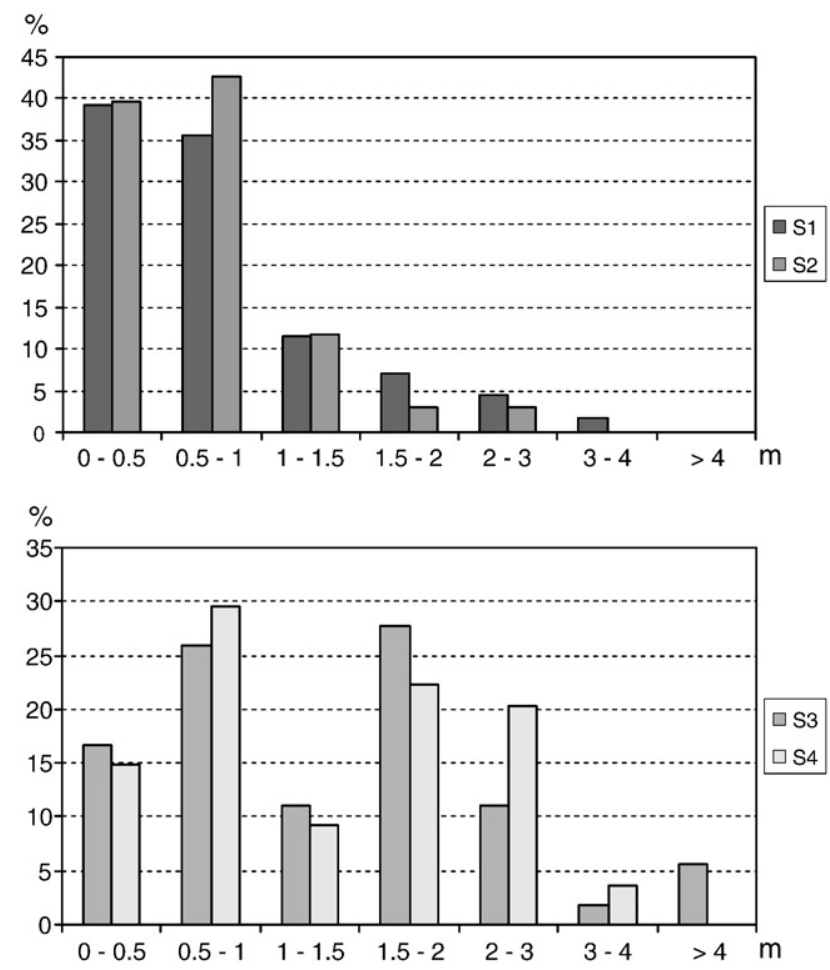

Fig. 8. Histograms showing dike thickness distribution of the four swarms.

The group of dikes constituting S3 (only 15\% of the whole) produce 32352 valid intersections. The centre of the swarm (C3, Fig. 7) has 280.750 and 3.112 .750 UTM coordinates. $83 \%$ of the valid intersections is included within a radius of $2.5 \mathrm{~km}$ around that point. These dikes, with much younger ages (5.5-4.4 Ma), are basaltic or intermediate in composition. Their thickness are larger than for all other swarms (average: $1.6 \mathrm{~m}$, median: $1.5 \mathrm{~m}$ ), show a bimodal distribution with a maximum between 0.5 and $1 \mathrm{~m}$, and another one between 1.5 and $2 \mathrm{~m}$ (Fig. 8).

Finally, the remaining $19 \%$ of dikes forms a fourth swarm (S4) producing 50712 valid intersections. The centre of this swarm (C4, Fig. 7) is given by the 282.250 and 3.110.750 UTM coordinates. The corresponding circle, $2.5 \mathrm{~km}$ in radius around that point, includes $92 \%$ of the intersections. These dikes display radiometric ages between 5.3 and $4.0 \mathrm{Ma}$ (Table 1) and are analogous in thickness and composition to the $\mathrm{S} 3$ dikes average: $1.7 \mathrm{~m}$, median: $1.5 \mathrm{~m}$ ).

\section{Discussion and conclusions}

According to the crosscutting field relationships, as well as to the age of the corresponding wall rock, the oldest swarm (post Basal Complex) is the population of slightly inclined dikes or sills. We have dated two sills (Table 1), one on the eastern and one on the western part of the island which giving ages of $9.4 \pm$ $0.6 \mathrm{Ma}$ (G-22) and 9.3 $\pm 0.8 \mathrm{Ma}$ (G-7) respectively (Ancochea et al., 2006). Cantagrel et al. (1984) had previously dated a dike at $10.2 \pm 0.5 \mathrm{Ma}$ which according to their description shows "sinuous disposition, and lack of vertical continuity", we interpret as a slightly inclined dike of the sills population.
On the basis of the radiometric ages of their dikes and of the rocks they cross, swarms S1 and S2 must be closely related to the Old Edifice. More specifically, S1 dikes (known ages comprised between 9.1 and $8.4 \mathrm{Ma}$ ) are mostly feeders of the uppermost levels in the LOE (10.5-8.6 Ma). As for the S2 dikes (8.2-6.7 Ma) they built up the UOE (8.6-6.4 Ma). Two different growth stages distinguished within the latter edifice (UOE-1 and UOE-2 in Ancochea et al., 2006) do not seem to be associated with different swarms.

Swarms S3 an S4 are associated with the Young Edifice. As it is inferred from the radiometric data, S3 (dikes dated between 5.5 and $4.4 \mathrm{Ma}$ ) may be linked with the first growth stage of the edifice (YE-1, Ancochea et al., 2006) that was built up in a period of time extending from 5.7 to $4.7 \mathrm{Ma}$, whilst S4 (dikes dated between 5.3 and $4.0 \mathrm{Ma}$ ) is more likely related to the second and last stage (YE-2) from which rock samples show radiometric ages between 4.4 and $4.2 \mathrm{Ma}$.

Each one of the centres inferred for any of the swarms can be considered to represent the main eruptive centre on the island over the corresponding period of time. On the other hand, taking into account the position of the successive dike swarms centres as a whole, a nearly $\mathrm{N}-\mathrm{S}$ migration of the major activity in the island is observed. This migration direction $\left(\mathrm{N} 165^{\circ}-170^{\circ}\right)$ is more or less normal to the direction of maximum spreading recorded in the Basal Complex of La Gomera (Fig. 9). The migration trend inferred from the successive radial swarm centres is likely the main regional trend. According to the age data, the volcanic activity has needed about $5 \mathrm{Ma}$ (from $9 \mathrm{Ma}$ to $4 \mathrm{Ma}$ ) to migrate from $\mathrm{C} 1$, the earliest and northernmost centre, towards $\mathrm{C} 4$, the youngest and southernmost one. As these two centres are separated some $8 \mathrm{~km}$ from each other, an average velocity of about $1.6 \mathrm{~mm} /$ year for such a migration is inferred.

A similar velocity for the migration of the volcanic activity is quoted for Lyttelton volcano, Banks Peninsula, New Zealand. This volcano, which is Upper Miocene in age, resembles the OE

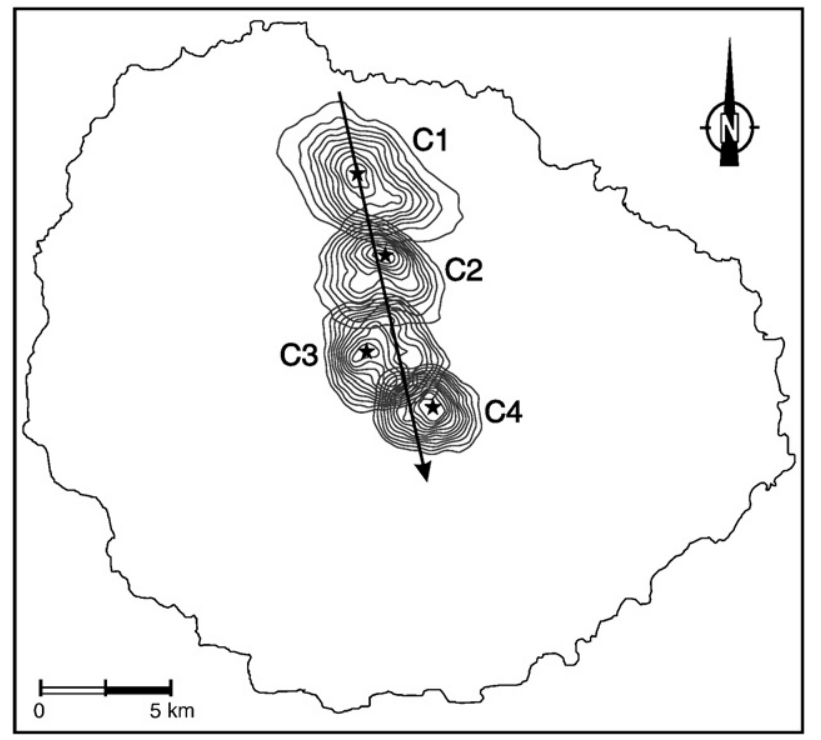

Fig. 9. Location of the four volcanic centres defined by the convergence of dikes ascribed to the respective swarms. Isolines as in Fig. 7. Arrow indicating migration of volcanic activity. 
of La Gomera. The network of dikes, interpreted by Speight (1938) as a radial swarm, has a centre which has been localised by Frost (1965). As in our study, Shelley (1987) has more recently distinguished two different swarms and has also deduced that the activity migrated about $2.7 \mathrm{~km}$ over a 2 million years time span, showing a similar migration velocity to that inferred from the dike swarms of La Gomera.

The fact of La Gomera having an almost circular shape has traditionally been interpreted as the result of the built up of a single large volcanic edifice. However, the study of these successive radial swarms of basic dikes shows that the island has gradually grown southwards but, because of the slow displacement of the magmatic focus, La Gomera does not display the $\mathrm{N}-\mathrm{S}$ elongated shape which would be expected.

The dikes trend and the stress field on La Gomera have varied with time. The Basal Complex dikes mostly represent the feeders of the Submarine Edifice. These feeders are characterised by their abundance and complexity in spite of their dominant $\mathrm{N} 70^{\circ}-80^{\circ}$ strike. This is a regional structural trend in the Canarian archipelago. MacFarlane (1968) and Dash and Bosshard (1969) detected by seismic and gravimetrical methods a major fracture line coinciding with that direction which extends from El Hierro through out the northern part of La Gomera (where the Basal Complex appears) up to Teno and Anaga Massifs, both in northern Tenerife. Dikes in that direction are not observed in Teno Massif (Féraud et al., 1985; Anguita and Hernán, 1986; Marinoni and Gudmunsson, 2000; Walter and Schmincke, 2002). Nevertheless, as the lowermost levels in Teno are not exposed (Ancochea et al., 1990) they may have existed in the very early growth stages equivalents to those of La Gomera. The same direction is dominant in all the stratigraphic levels and especially in the lowermost ones of Anaga where dikes represent $85 \%$ of the exposed rock (Hernández Pacheco and Rodríguez Losada, 1996).

The local stress fields controlled the emplacement of the following dike systems. Firstly, the sills intruded in the LOE representing the submarine-subaerial transition and also the very early stage of the subaerial growth essentially characterised by pahoehoe lava flows. Secondly, the different radial swarms associated with the subsequent subaerial growth stages.

Similar evolution patterns, that is: parallel swarms in the Basal Complex, sills in the Submarine Edifice or in the first subaerial stages and radial swarms in the edifice subaerial growth are appreciated in others oceanic islands. In the Canarian archipelago for example, in La Palma abundant sills are associated with pillow lavas of the submarine stage (Staudigel and Schmincke, 1984), whilst later dikes follow radial patterns (De la Nuez, 1984; Ancochea et al., 1994, Fernández et al., 2002). In Fuerteventura, sills are absent in submarine rocks of the Basal Complex (Gutiérrez et al., 2006). However, a similar variation is observed in the dike swarms: the Basal Complex dikes maintain a dominant regional $\mathrm{N} 10^{\circ}-20^{\circ}$ direction (Fúster et al., 1968; López Ruiz, 1970; Stillman, 1987; Ahijado et al., 2001) and the subaerial edifices (aligned following regional trends) exhibit radial dikes swarms (Ancochea et al., 1996). Also in the Cabo Verde archipelago, in San Vicente island, sills are dominant during the first subaerial growth stages of the main volcanic edifice while afterwards radial dikes swarms are the dominant ones (Huertas et al., 2006).

\section{Acknowledgements}

The Project BTE 2003-02153, CGL2006-03414 and G.I. 910469 UCM-CAM supported this work. Prof. Allister Horbury revised the English version of the manuscript. The authors thank the reviewers for their constructive remarks. This work was inspired and aimed by our colleague and friend Prof. Carmen Rosa Cubas who also collaborated with us. She was born in La Gomera and passed away in March 2003.

\section{References}

Abdel Monen, A., Watkins, N.D., Gast, P.W., 1971. Potassium-argon ages, volcanic stratigraphy, and geomagnetic polarity history of the Canary Islands: Lanzarote, Fuerteventura, Gran Canaria and La Gomera. Am. J. Sci. 271, 490-521.

Ahijado, A., Casillas, R., Hernández Pacheco, A., 2001. The dike swarms of the Amanay Massif, Fuerteventura. Canary Islands. J. Asian Earth Sci. 19, 333-345.

Ancochea, E., Fúster, J.M., Ibarrola, E., Cendrero, A., Coello, J., Hernán, F., Cantagrel, J.M., Jamond, C., 1990. Volcanic evolution of the Island of Tenerife (Canary Islands) in the light of new $\mathrm{K}-\mathrm{Ar}$ data. J. Volcanol. Geotherm. Res. 44, 231-249.

Ancochea, E., Brändle, J.L., Cubas, C.R., Hernán, F., Huertas, M.J., 1993. La Serie I de Fuerteventura. Mem. R. Acad. Cienc. Exactas, Fis. Nat. Madrid 27 $151 \mathrm{p}$.

Ancochea, E., Hernán, F., Cendrero, A., Cantagrel, J.M., Fúster, J.M., Ibarrola, E., Coello, J., 1994. Constructive and destructive episodes in the building of young Oceanic Island, La Palma, Canary Islands and genesis of the Caldera de Taburiente. J. Volcanol. Geotherm. Res. 60, 243-262.

Ancochea, E., Brändle, J.L., Cubas, C.R., Hernán, F., Huertas, M.J., 1996. Volcanic complexes in the eastern ridge of the Canary Islands: the Miocene activity of the island of Fuerteventura. J. Volcanol. Geotherm. Res. 70, $183-204$

Ancochea, E., Huertas, M.J., Cantagrel, J.M., Coello, J., Fúster, J.M., Arnaud, N., Ibarrola, E., 1999. Evolution of the Cañadas edifice and its implications for the origin of the Cañadas Caldera (Tenerife, Canary Islands). J. Volcanol. Geotherm. Res. 88, 177-199.

Ancochea, E., Brändle, J.L., Huertas, M.J., Cubas, C.R., Hernán, F., 2003. The felsic dikes of La Gomera (Canary Islands): Identification of cone sheet and radial dike swarms. J. Volcanol. Geotherm. Res. 120, 197-206.

Ancochea, E., Hernán, F., Huertas, M.J., Brändle, J.L., Herrera, R., 2006. A new chronostratigraphical and evolutionary model for La Gomera: implications for the overall evolution of the Canarian Archipelago. J. Volcanol. Geotherm. Res. 157, 271-293.

Anderson, E.M., 1951. The Dynamics of Faulting and Dyke Formation with Applications to Great Britain. Oliver and Boyd, Edinburgh. 206 pp.

Anguita, F., Hernán, F., 1986. Discussion to "Geochronology of some canarian dike swarms: contribution to the volcano-tectonic evolution of the archipelago" by Féraud G., Giannerini, G., Campredon, R., Stillman, C.J. J. Volcanol. Geotherm. Res. 30, 155-162.

Brändle, J.L., Ancochea, E., Cubas, C.R., Hernán, F., 1991. Análisis de enjambres de diques radiales utilizando un método matemático. Geogaceta 10, 97-100.

Brändle, J.L., Cubas, C.R., Huertas, M.J., Hernán, F., Ancochea, E., 2001. Edad de los diques sálicos del Norte de la isla de La Gomera. Geogaceta 30, $171-173$

Bravo, T., 1964. Estudio geológico y petrográfico de la isla de La Gomera. Est. Geol. 20, 1-56.

Cantagrel, J.M., Cendrero, A., Fúster, J.M., Ibarrola, E., Jamond, C., 1984. KAr Chronology of the Volcanic Eruption in the Canarian Archipelago: Island of La Gomera. Bull. Volcanol. 47, 597-609. 
Cendrero, A., 1970. The Volcano-plutonic complex of La Gomera (Canary Islands). Bull. Volcanol. 34, 537-561.

Cendrero, A., 1971. Estudio geológico y petrológico del Complejo Basal de la Isla de La Gomera (Islas Canarias). Est. Geol. 27, 3-73.

Coello, J., Cantagrel, J.M., Ibarrola, E., Jamond, C., Hernán, F., Fúster, J.M., Ancochea, E., Casquet, C., Díaz de Terán, J.R., Cendrero, A., 1992. Evolution of the eastern volcanic ridge of the Canary Islands, based on new $\mathrm{K}-\mathrm{Ar}$ data. J. Volcanol. Geotherm. Res. 53, 251-274.

Cubas, C.R., 1978a. Estudio de los domos sálicos de la isla de La Gomera (Islas Canarias).I. Vulcanología. Est. Geol. 34, 53-70.

Cubas, C.R., 1978b. Estudio de los domos sálicos de la isla de La Gomera (Islas Canarias).II. Geoquímica. Est. Geol. 34, 107-128.

Cubas, C.R., Hernán, F., Ancochea, E., Brändle, J.L., Huertas, M.J., 1994. Serie Basáltica Antigua Inferior en el sector de Hermigua. Isla de la Gomera. Geogaceta 16, 15-18.

Cubas, C.R., Ancochea, E., Hernán, F., Huertas, M.J., Brändle, J.L., 2002. Edad de los domos sálicos de la isla de La Gomera. Geogaceta 32, 69-72.

Dash, B.F., Bosshard, E., 1969. Seismic and gravity investigations around the western Canary Islands. Earth Planet. Sci. Lett. 7, 169-177.

De la Nuez, J., 1984. El complejo intrusivo subvolcánico de la Caldera de Taburiente. La Palma (Canarias). Tesis Doctoral. Univ. Complutense de Madrid, $401 \mathrm{pp}$.

Féraud, G., 1981. Datation de réseaux de dykes et de roches volcaniques sousmarines par les méthodes $\mathrm{K}-\mathrm{Ar}$ et $40 \mathrm{Ar}-39 \mathrm{Ar}$. Utilisation des dykes comme marqueurs de paléocontraites. Thèse Doctorat. Lab. Geol. Geochimie. Fac. Sci. Tech. Univ. de Nice, 146 pp.

Féraud, G., Giannerini, G., Campredon, R., Stillman, C.J., 1985. Geochronology of some canarian dike swarms: contribution to the volcano-tectonic evolution of the archipielago. J. Volcanol. Geotherm. Res. 25, 29-52.

Fernández, C., De la Nuez, J., Casillas, R., García, E., 2002. Stress fields associated with the growth of a large shield volcano (La Palma. Canary Islands). Tectonics 20, 367-384.

Fúster, J.M., Cendrero, A., Gastesi, P., Ibarrola, E., López Ruiz, J., 1968. Geología y volcanología de las Islas Canarias-Fuerteventura. Inst. Lucas Mallada. CSIC, Madrid. 239 pp.

Frost, M.J., 1965. Centre-finding in Systems of Lines. Geol. Mag. 102, $445-450$.

Gutiérrez, M., Casillas, R., Fernández, C., Balogh, K., Ahijado, A., Castillo, C., Colmenero, J.R., García-Navarro, E., 2006. The submarine volcanic sucesión of the basal complex of Fuerteventura, Canary Island: A model of submarine growth and emergente of tectonic volcanic islands. Bull. Geol. Soc. Am. 118, 785-804.

Harker, A., 1904. The Tertiary igneous rocks of Skye. Mem. Geol. Surv., U.K. $1-148$.

Hausen, H., 1971. Outlines of the geology of Gomera. Soc. Scient. Fen. Com. Phys. Mathem. 41, 1-53.

Hernán, F., 1976. Estudio petrológico y estructural del complejo traquíticosienítico de Gran Canaria. Est. Geol. 32, 279-324.

Hernán, F., Cubas, C.R., Huertas, M.J., Brändle, J.L., Ancochea, E., 2000. Geometría del enjambre de diques cónicos de Vallehermoso. La Gomera (Islas Canarias). Geogaceta 27, 125-129.

Hernández Pacheco, A., Rodríguez Losada, J.A., 1996. Geología y estructura del Arco de Taganana (Tenerife, Canarias). Rev. Soc. Geol. Esp. 9, 169-181.

Herrera, R., Ancochea, E., Huertas, M.J., 2006. Las rocas volcánicas del Edificio Submarino de la Isla de La Gomera: características composicionales. Geogaceta 39, 43-46.
Huertas, M.J., Brändle, J.L., Ancochea, E., Hernán, F., Cubas, C.R., 2000. Distribución de los diques sálicos del Norte de La Gomera. Geogaceta 27, 133-137.

Huertas, M.J., Hernán, F., Ancochea, E., Brändle, J.L., 2006. El Edificio Antiguo de la isla de San Vicente (Cabo Verde): características del sector occidental. Geogaceta 40, 95-98.

López Ruiz, J., 1970. Estudio petrográfico y geoquímico del Complejo Filoniano de Fuerteventura. (Islas Canarias). Est.Geol. 26, 173-208.

Marinoni, L.B., Gudmunsson, A., 2000. Dykes, faults and palaeostress in the Teno and Anaga massifs of Tenerife (Canary Islands). J. Volcanol. Geotherm. Res. 103, 83-103.

MacFarlane, D.J., 1968. Ph. D. Thesis, University of London, unpublished paper.

Ode, H., 1957. Mechanical analysis of the dyke pattern of Spanish Peaks area, Colorado. Bull. Geol. Soc. Am. 68, 567-578.

Paris, R., Guillou, H., Carracedo, J.C., Pérez Torrado, F.J., 2005. Volcanic and morphological evolution of La Gomera (Canary Islands), based on new $\mathrm{K}-\mathrm{Ar}$ ages and magnetic stratigraphy: implications for oceanic island evolution. J. Geol. Soc. (Lond.) 162, 501-512.

Richey, J.E., 1939. The dykes of Scotland. Trans. Geol. Soc. Edinburgh 13 , 393-435.

Rodríguez Losada, J.A., 1987. Un complejo de diques cónicos en la isla de La Gomera, Islas Canarias. Est. Geol. 43, 41-45.

Rodríguez Losada, J.A., 1988. El Complejo Traquítico-Fonolítico de La Gomera. Tesis Doctoral. Univ. Complutense de Madrid, 414 pp.

Rodríguez Losada, J.A., Martínez Frías, J., 2004. The felsic complex of the Vallehermoso Caldera: interior of an ancient volcanic system (La Gomera, Canary Islands). J. Volcanol. Geotherm. Res. 137, 261-284.

Schirnick, C., Bogaard, P.D., Schmincke, H.U., 1999. Cone sheet formation and intrusive growth of an oceanic island. The Miocene Tejeda complex on Gran Canaria (Canary Islands). Geology 27, 207-210.

Schmincke, H.U., 1967. Cone sheet swarm, resurgence of Tejeda Caldera, and the early geologic history of Gran Canaria. Bull. Volcanol. 31, 153-162.

Shelley, D., 1987. Lyttelton 1 and Lyttelton 2, the two centres of Lyttelton Volcano. N.Z. J. Geol. Geophys. 30, 159-168.

Speight, R., 1938. The dykes if the Summit Road, Lyttelton. Trans. R. Soc. N.Z. 68, 82-99.

Speight, J.M., Skelhorn, R.R., Sloan, T., Knapp, R.J., 1982. The dyke swarms of Scotland. In: Sutherland, D.S. (Ed.), Igneous rocks of the British Isles. Wiley, New York, pp. 449-459.

Staudigel, H., Schmincke, H.U., 1984. The Pliocene seamount series of La Palma (Canary Islands). J. Geophys. Res. 89, 11195-11215.

Staudigel, H., Féraud, G., Giannerini, G., 1986. The history of intrusive activity on the island of La Palma (Canary Islands). J. Volcanol. Geotherm. Res. 27, 299-322.

Stillman, C.J., 1987. A Canary Islands dyke swarm: implications for the formation of oceanic islands by extensional fissural volcanism. In: Halls, H.C., Fahrig, W.J. (Eds.), Mafic dyke swarms. Geol. Assoc. Can. Spec. Pap., vol. 34, pp. 243-255.

Walter, T.R., Schmincke, H.U., 2002. Rifting, recurrent landsliding and Miocene structural reorganitation on NW-Tenerife (Canary Islands). Int. J. Earth Sci. (Geol. Rundsch.) 91, 615-628. 